\title{
UNIVERSITY JUBILEES AND UNIVESITY HISTORY WRITING: A CHALLENGING RELATIONSHIP
}

\author{
Szerkesztette Pieter Dhondt \\ (Leiden-Boston, Brill, 2014, 257 lap)
}

Az utóbbi évtizedekben Európa-szerte megélénkülő és módszertani tekintetben is jelentősen gazdagodó egyetemtörténeti kutatásnak impozáns megnyilvánulási fórumait jelentették az évfordulók, az intézményi jubileumok, amelyek számos különböző formát öltöttek a társadalmi nyilvánosságban. Reprezentatív ünnepségek, tudományos konferenciák, kiállítások, muzeológiai rendezvények, emléktárgyak készítése és vására vagy éppen koncertek, színházi előadások szervezése révén fejeződött ki az emlékezet fenntartására irányuló törekvés, amely az intézményi identitás időbeli dimenzióját kívánta demonstrálni. Mindezek természetesen az egyes egyetemek rangját igyekeztek emelni, működésük időbeli mélysége megbízhatóságukat, időtálló teljesítményüket volt hivatva illusztrálni, ez pedig a 21. században, az intézmények divatos rangsorolása és rivalizálása során különlegesen is fontossá vált. A Genti Egyetemen végzett kutató, Pieter Dhondt (jelenleg a University of Eastern Finland, Joensuu vendégoktatója) Európaszerte ismert szakembere a témának, az utóbbi évtizedben számos univerzitástörténeti tanulmányt publikált. Legismertebb korábbi szerkesztett könyve a skandináv egyetemek identitásának kérdőjeleit sorakoztatta fel, és ebből a nézőpontból azok 19. századi évfordulóit vette górcső alá szerzőtársaival együtt. ${ }^{1}$ A most bemutatandó, általa szerkesztett kötet az egyes európai univerzitások történetében az évfordulók szerepének vizsgálatát tűzte ki célul, s a különböző európai egyetemek múltját kutató szakemberek tanulmányaiból állított össze olyan komparatív szemléletü körképet, amely módszertanilag is számos tanulságot kínál az egyetemtörténeti kutatások számára.

A bevezetésben a szerkesztő felteszi a kérdést: vajon több-e az egyetemtörténet mint csupán az intézmény évfordulóin elhangzott megemlékező előadások összessége? Csupán a történetírás érdekkörébe tartozik-e a téma, avagy jóval tágabb kontextusba illeszkednek az ilyen reprezentatív megemlékezések? Mennyiben gazdagodhat a reprezentációs szándékok mellett a tudománytörténet az évfordulós rendezvények során? A válasz szerint a jubileumok ugyan jó alkalmai az intézménytörténeti kutatómunka

${ }^{1}$ National, Nordic or European? Nineteenth-Century University Jubilees and Nordic Cooperation, ed. Pieter Dhondt, Leiden-Boston, 2011. 
bemutatásának, de a történészi feladat semmiképp nem merülhet ki a visszaemlékezések összegyűjtésében, csakis a szisztematikus levéltári feltárás hozhat valós eredményeket. Rövid historiográfiai áttekintést is kapunk itt: a 16. századi kezdemények után az egyetemek történetének feltárásában a 19. század jelentette az első virágkort, ekkor már önálló kötetek jelentek meg a nagyobb intézmények jubileumaira, megkezdődött az önálló tudományos/ideológiai/szellemi formációk konstrukciója, az emlékezetkultúra és a történettudomány egymásra talált a szerencsésebb esetekben. A szerkesztő szerint a földrajzi-regionális, a kronológiai és a tematikus irányzatú egyetemtörténeti kutatások egyaránt termékeny szempontokkal gazdagították az egyetemek múltjának feltárását.

A tíz tanulmányt tartalmazó kötet három nagy egységre tagolva mutatja be az egyetemtörténeti kutatómunka európai körképét vagy legalábbis annak fontosabb újabb tendenciáit. Az első tömb azt a jelenséget elemzi, amelynek során az egyetemek múltjának felidézése a jubileumi ünnepségek részévé, elengedhetetlen tartozékává vált, ezt azonban a politikai körülmények mindig is befolyásolták. Itt elsőként az 1348-ban IV. Károly császár által alapított prágai Károly Egyetem (Universitas Carolina Pragensis, 1654-1918 között: Universitas Carolo-Ferdinando, ma: Univerzita Karlova v Praze) két nagyszabású - s mindjárt hozzátehetjük: viharos lefolyású - évfordulójáról esik szó (Marek Ďurčansky, Pieter Dhondt). Ez az esettanulmány markánsan illusztrálja a kiinduló hipotézist: mind az ötszáz éves jubileumon, 1848-ban, mind száz évvel később, 1948-ban ambiciózus ünnepséggel készült az intézmény az évforduló megünneplésére, de mindkét eseményt jelentékeny mértékben befolyásolták, megzavarták a politikai történések. 1848-ban diáktüntetések zajlottak, a hallgatók követelték a nyelvi és felekezeti egyenlőséget, a cseh nyelv használatát az oktatásban, száz évvel később viszont a kommunista hatalomátvétel korlátozta az egyetemi autonómiát, elbocsátásokra került sor, ez okozott nem csekély mértékü feszültséget. Egyik évforduló sem zajlott tehát az egyetemi tradíció zavartalan megünneplésének jegyében, ami azonban ennél fontosabb: mindkettő hozott eredményeket is. 1848-ban avathatták fel az alapító Károly császár reprezentatív emlékművét Prága egyik központi terén, s ekkor készült el az első nagyszabású, levéltári forrásokon alapuló egyetemtörténeti monográfia is Vaclav Vladivoj Tomek történész munkájaként. ${ }^{2} A$ mű német változata szintén megjelent még ugyanebben az évben, „zur Feier der fünfundertjährigen Gründung”, azaz kétségkívül a jubileumi alkalom hívta életre. Noha a másik tárgyalt évforduló is ugyancsak feszültségekkel volt terhes, ám a politikai konfliktusok ellenére ez sem volt eredménytelen, a hatóságok belátták, hogy bizonyos gesztusokat kell tenniük, így került sor az ősi egyetemi épületek közül többnek a felújítására, a berendezés modernizálására. A tanulmány szerzői szerint a politikai viharoknak voltak ugyan áldozatai, számos tanárt és diákot elbocsátottak, elszalasztott lehetőségekről is lehet beszélni, azonban a nézetek és felfogások összecsapása eredményeket is hozott, végeredményben a prágai egyetemet immár több mint hat évszázada Közép-Európa legrangosabb, legrégebbi hagyományokkal rendelkezö, tekintélyes intézményeinek egyikeként tartja számon a nemzetközi tudományos közvélemény.

\footnotetext{
${ }^{2}$ Vaclav Vladivoj Tомек, Děje university Pražske, Praha, 1849.
} 
Míg Prágában a Károly Egyetem nagy tradícióval rendelkező, középkori alapítás, addig a következő tanulmány egy jóval fiatalabb intézmény jubileumának eseményeit mérlegeli, s ennek tükrében élesen, szándékosan provokatív módon veti fel a kérdést: vajon a Kristianiai (ma. Oslói) Királyi Frederick Egyetem (Det Kongelige Frederiks Universitet) „észak intellektuális jelzőtüze” (,intellectual beacon of the North”) volt-e, vajon Skandinávia szellemi öntudatra ébredésének, igényességének jelképét láthatjuk-e benne, avagy csak egy „északnémet provinciális intézmény” maradt-e? A német univerzitások szegény északi rokona szerepét kellett-e betöltenie? A sokatmondó kérdés már önmagában hordja a választ: Norvégia szempontjából természetesen nagy jelentősége volt a VI. Frigyes dán-norvég uralkodó által 1811-ben alapított egyetemnek, még akkor is, ha a nagy hagyományokkal rendelkező német egyetemtörténet szempontjából ez a kontinens peremterületén működő, külföldi segítségre szoruló kezdeményezésnek számított. Az alapítás után a koppenhágai és a berlini egyetem modelljei alapján szervezték meg az ottani oktatást, az önálló intézményi arculat és szellemiség csak fokozatosan fejlődhetett ki, de a százéves évfordulón tartott ünnepség 1911-ben már erős identitástudattal rendelkező intézményt mutatott, a norvég szerző tanulmánya ezt a folyamatot kíséri figyelemmel (Jorunn Sem Fure). Fejtegetése azért tanulságos, mert a viszontagságos politikai körülmények között vergődő, mégis fejlődő intézmény múltja sok tekintetben modellálni tudja a kontinens peremrégióiban létesített, új alapítású univerzitások sorsát, helyzetét, fejlődésvonalát, lehetőségeit.

Egészen más kérdések kerülnek előtérbe a nagy német és orosz egyetemeknek az I. világháborút megelőző évfordulói kapcsán. Az 1912-ben és 1913-ban megrendezett jubileumi ünnepségek a téma göttingeni kutatója szerint a nemzeti büszkeség hangsúlyozásának lettek alkalmai (patriotic anniversaries), az elkötelezettség és öntudat szólamai, valamint az önérvényesítési törekvések határozták meg a rendezvények retorikáját (Trude Maurer). A nemzeti identitástudat kialakításában ezek az intézmények kiemelkedő szerepet játszottak (Göttingen, Berlin, Lipcse, Freiburg, Breslau, másfelől Moszkva, Szentpétervár, Harkov vagy éppen Kazany).

Az első egység zárásaként a kolozsvári egyetemi jubileumok 1919 és 2009 közötti éveinek reprezentációját tekinti át a Sorbonne-on doktorált román kutató (Ana-Maria Stan), aki egyébként a román-francia politikai és kulturális kapcsolatok történetének specialistája. A magyar egyetemtörténet szempontjából is tanulságos tanulmánya négy alfejezetre osztva mutatja be a kolozsvári univerzitás történeti évfordulóinak sorát. Elsőként tárgyalja azt a felavatási-beiktatási ünnepséget (Inauguration Ceremony), amelyet a román állam a trianoni békeszerződés értelmében hozzá került intézmény birtokbavételének alkalmából rendezett meg. Az 1872-ben Ferenc József császár és király által felavatott magyar egyetemet 1920-tól Románia elit intézményeként jelenítették meg a politikai nyilvánosságban, ennek tudatosítását szolgálta az 1920. február 1-jén és 2-án nagy pompával megtartott ünnepi rendezvénysorozat. A román politika a strasbourgi egyetem tulajdonoscseréjével igyekezett ezt párhuzamba állítani, mindkét esemény jóval több volt, mint egyetemi reprezentáció: kiemelkedő politikai és nem- 
zeti identitásképző jellege nyilvánvalóvá vált. Nem véletlen, hogy az egyetem vezetői ünnepi köszöntőikben a poroszos oktatási minta helyett a liberálisabb francia példa követését hangsúlyozták jövendőbeli terveiket illetően. Az erdélyi város ünnepségére meghívott külföldi delegátusok a neolatin kultúra újabb európai centrumaként, végváraként említették köszöntő szónoklataikban a román univerzitást, a holland követ pedig az évszázados peregrinációs kapcsolatokat is szóba hozta. A tanulmány második alfejezete a tízéves jubileumi ünnepséget, az 1930-as évforduló eseményeit mutatja be, kiemelve az akkor trónra került és ott megjelent II. Károly román király jelenlétét, amely a politikai reprezentáció szempontjából jelentősen erősítette az intézmény presztízsét. A harmadik decennális emlékév 1940-ben már a magyar-román határmódosítás jegyében ismét más körülmények között telt el, erről a szerző az Ovidiu Ghitta által szerkesztett, s 2012-ben kiadott egyetemtörténeti monográfia megfelelő fejezetére utal (erről szól a Gerundium 2016/3-4. számában Nagy Levente ismertetése). Indokoltan teszi, mert a „magyar korszak”, az 1940-1944 közötti évek leghitelesebb bemutatásának ez tekinthető. Végül a Babes-Bolyai kettős névadás körülményeit, majd pedig az új korszak egyetemi eseményeit, a „vasfüggöny lehullása” utáni ünnepségeket jellemzi a szerző. Végső következtetése szerint a politikai széljárás szeszélyeinek különösen is kitett kolozsvári egyetem sorsa jól példázza, hogy a jubileumi ünnepségeknek és emlékező rendezvényeknek - amelyek az intézmények történetének megírását hathatósan elősegíthetnék - sajnálatosan gyakran az éppen uralmon lévő politikai elit elvárásait kellett kiszolgálniuk. Éppen ezért a jubileumtörténeti vizsgálódások tanulságait célszerű lenne megfontolniuk mindazoknak, akik a jövőben ilyeneket rendeznek, így többek között a 2020-as centenáriumi évre készülő kolozsvári egyetemi vezetésnek is.

A tanulmánykötet második blokkja a jubileumi alkalmakra készült egyetemtörténetekről szól, de csupán két tanulmányt tartalmaz. Az első ismét egy norvég példát mutat be: a szerző a Trondheimi Egyetem (Norwegian University of Science and Technology Located in Trondheim) 1968-as jubileumát fordulópontként értékeli az intézmény történetében (Thomas Brandt). Ekkor kezdődött valójában az egyetem múltkonstrukciója, amely az 1767-ben alapított tudós társaságot (Royal Norwegian Society of Scineces and Letters) kezdte az egyetem előzményének értelmezni, s így kétszáz éves évfordulót ünnepelt. De 2010-ben már kétszázötven éves jubileumról lett szó, mivel kiderítették, hogy a jelzett társulat előzménye már 1760-ban is működött. Beszédes példája ez az eset annak, hogy az egyes intézmények rendkívüli súlyt helyeznek múltjuk időbeli mélységeinek feltárására, s ez a 21. században is presztízsnövelő tényezőnek számít. Módszertani szempontból ez a törekvés veszélyeket is rejt magában, mivel egyes univerzitások különféle rangú és súlyú tudós társaságokat is előzményeiknek kezdenek tekinteni, s így igyekeznek történetüket mind korábbi időszakra datálni.

A másik tanulmány a lipcsei egyetemen folyó intézménytörténeti kutatásokról számol be, számos projektet és vizsgálódási területet mutatva be (Jonas Flöter). Az itteni egyetemtörténeti kutatóközpont (Verein für Leipziger Universitätsgeschichte) az egyik legjelentősebb fóruma ennek a tudományterületnek. A lipcsei egyetem (Alma Mater 
Lipsiensis) 1409-tól számítja fennállását, IV. Frigyes őrgróf és az Ágoston-rendi kanonok ekkor alapították azt meg, így 2009-ben ünnepelhette 600 éves évfordulóját. Egykori diákjai és tanárai között az intézmény számos világhírességet tart számon (pl. Leibniz, Goethe, s a Nobel-díjasok közül Werner Heisenberg, Wilhelm Ostwald), érthető hogy már másfél évtizeddel a nagy jubileum előtt elkezdődtek az előkészületek egy új egyetemtörténet megírására. A szenátus által megbízott egyetemtörténeti bizottság koordinátora, Jonas Flöter azt a folyamatot mutatja be, amelynek során a szerkesztőknek szembe kellett nézniük számos módszertani kérdéssel és dilemmával, míg végre elkészülhetett az ötkötetes monográfia. ${ }^{3}$ Egy külön kiadványban adták közre a jubileummal kapcsolatos összes dokumentumokat (2011), így az évforduló tudományos hozama mellé ünnepi reprezentációjának bemutatását is csatolták.

A harmadik tematikai egység három írása azt a kérdést vizsgálja, hogy egyes évfordulók után miképpen folytatódott az érintett helyeken az intézménytörténeti kutatás, miképpen hatott a jubileum a rendszeres feltáró munkálatokra. Képet kapunk itt a humboldti tradícióról, a berlini egyetem arculatának átformálódásáról az 1800 és 1945 közötti másfél évszázadot tekintve (Johan Östling). A szerző újszerű megállapítása, hogy az 1810-ben II. Frigyes Wilmos porosz uralkodó támogatásával Wilhelm von Humboldt elméleti modellje szerint létrehozott intézmény, amely tanítás (Bildung, levezetve az ógörög paidea ideájából) és kutatás (Forschung) összhangját és a tudományok egységét kívánta megtestesíteni, a centenárium idejére több tekintetben átformálódott, $s$ a német nemzeti kultúrát reprezentáló intézménnyé vált. A szerző bemutatja a két korszak - az alapítás és a centenárium - politikai kontextusa közötti különbségeket, valamint a humboldti örökség értelmezésének alakulását, hangsúlyainak átrendeződését a 19. század folyamán. A Német Birodalom egyetemeinek száma az I. világháborúig húsz fölé emelkedett (Münster 1902, Frankfurt am Main 1914), ebben a hálózatban kívánt vezetô szerephez jutni a berlini intézmény, amely most már nem csupán a kontinens, de Amerika egyre rangosabb intézményeivel is rivalizálni volt kénytelen. Az 1910-es jubileum ezt az újradefiniálást szolgálta, visszanyúlva az eredeti humboldti örökség egyes elemeihez is. Végül a bicentenárium 2010-ben meghozta a berlini egyetem monumentális történeti szintézisének elkészítését is, a hat kötet szerzői kollektívája széles társadalmi körképben mutatja be az intézmény múltját. ${ }^{4} \mathrm{~A}$ tanulmány szerzője hangot ad annak a meggyőződésének, hogy a modern egyetemtörténet nem csupán a tradíciók megőrzésének helye kell hogy legyen, de az univerzitás fogalmának állandó újraértelmezése révén - közvetett módon - a jövő társadalmának, szellemi állapotának formálásban is kiemelkedő szerepet kell játszania

Egy másik, rövidebb tanulmány a francia helyzetet méri fel, a lyoni kutató elsősorban a tudományos együttműködések megélénkülésében látja az évfordulós inspirációk jelentőségét (Emmanuelle Picard). A sort $s$ vele együtt a kötetet a szerkesztő tanulmá-

3 Geschichte der Universität Leipzig 1409-2009, Hg. Enno Bünz, Manfred Rudersdorf, Detlef DöRING, Leipzig, Universitätsverlag, 2009.

${ }^{4}$ Geschichte der Universität Unter den Linden 1810-2010, Akademie Velag, Berlin, 2010-2013. 
nya zárja. Pieter Dhondt fejtegetése szerint az egyetemtörténet-írás a neveléstörténet része, ebben a szélesebb keretben látja kijelölhetőnek a diszciplína helyét. Ezt a megállapítást azonban a magunk részéről vitathatónak vagy legalábbis árnyalandónak véljük, mivel a magyarországi tapasztalat szerint elsősorban történészek (még pontosabban: művelődéstörténészek) foglalkoznak a felsőoktatás históriájával. Az egyetemek kialakulása és müködése ugyanis mindig egy meghatározott történeti kontextusban ment végbe, az adott korszak politikai körülményeitől függött a pozíciója, szerencsésebb tehát a kultúrtörténet részeként értelmezni a felsőoktatás múltjának feltárását.

A kötet egyes esettanulmányai önmagukban is informatív képet adnak az európai felsőoktatás történetének lényeges kérdéseiről, de talán ennél is fontosabbak módszertani tanulságai. Egyfelől ugyanis az ünnepi alkalmak a reprezentációra helyezték a hangsúlyt, s ilyenkor a lokális érdekek - olykor túlzott mértékủ lelkesedések - nem ritkán háttérbe szorították a higgadt és objektív történeti szemléletet, s ennek következményeként az igényes kritikai ábrázolást. A historikusnak célszerủ óvakodnia tehát a rövidtávú érdekek szolgálatától, meg kell keresnie a jubileumi érzelmek és a szakmai kritériumok között járható utat, még ha olykor keskenynek is mutatkozik az ilyen ösvény. A legtöbb egyetem történetében tanúi lehetünk a tudományos és politikai szempontok együttes érvényesülésének, minthogy az intézményi identitástudat és autonómia többé vagy kevésbé mindig függvénye volt a tágabb társadalmi környezetnek.

Ugyanakkor azonban az is megmutatkozik a tanulmányokban, hogy az államok életében - gyakran éppen önállósodási törekvéseikben - a középkor óta folyamatosan kiemelkedő szerepet játszottak az egyetemek, s ez a funkciójuk a modern korban egyáltalán nem csökkent, inkább még a felértékelödésnek lehetünk tanúi. Az is kiviláglik az esettanulmányokból, hogy érdemes lesz a jövőben az emlékezetkultúra (Erinnerungsforschung) eredményeivel és módszereivel még szorosabban összekapcsolni az egyes univerzitások történetének vizsgálatát, erre jó példát szolgáltatott már korábban Csáky Móritznak a bécsi egyetemről szóló tanulmánya. ${ }^{5} \mathrm{~A}$ tanulmánygyüjtemény írásainak többségét a régi egyetemi épületekről készült metszetek és egyéb illusztrációk kísérik, jól kiegészítve a fejtegetéseket, legfeljebb egy térképet hiányolhatunk az európai felsőoktatási térség megjelenítésére. Jó ötlet viszont a szerzők és munkásságuk részletes bemutatása, amely elősegíti a témakörben történő további tájékozódást és a nemzetközi kapcsolatok erősítését. Összességében az igényesen szerkesztett kötet az európai egyetemtörténet-írás fontos seregszemléje, $s$ a jövőben jól használható lesz mind az egyes egyetemek múltjának további feltárása, mind pedig a kutatás módszertanának fejlesztése szempontjából.

Bitskey István

${ }^{5}$ Moritz Csáky, Altes Universitätsviertel: Erinnerungsraum, Gedächtnisort = Die Verortung von Gedächtnis, Hg. Moritz Csáky, Peter Stachel, Wien, 2001, 257-277. 